\title{
The Paradox of Infinite Given Magnitude: Why Kantian Epistemology Needs Metaphysical Space
}

\author{
by Lydia Patton, Blacksburg
}

\begin{abstract}
Kant's account of space as an infinite given magnitude in the Critique of Pure Reason is paradoxical, since infinite magnitudes go beyond the limits of possible experience. Michael Friedman's and Charles Parsons's accounts make sense of geometrical construction, but I argue that they do not resolve the paradox. I argue that metaphysical space is based on the ability of the subject to generate distinctly oriented spatial magnitudes of invariant scalar quantity through translation or rotation. The set of determinately oriented, constructed geometrical spaces is a proper subset of metaphysical space, thus, metaphysical space is infinite. Kant's paradoxical doctrine of metaphysical space is necessary to reconcile his empiricism with his transcendental idealism.
\end{abstract}

Keywords: Space, geometry, construction, infinite

In the Transcendental Aesthetic, Kant gives four characteristics of the concept of space "als a priori gegeben". These are meant to show that space and time "nur an der Form der Anschauung allein haften, und mithin an der subjektiven Beschaffenheit unseres Gemüts". ${ }^{1}$ Kant says that space is "als eine unendliche gegebene Größe vorgestellt." 2 These two characteristics contradict one another prima facie, since we are not presented with infinite objects, quantities, magnitudes, or series in ordinary experience. With this paradox, interpreters of Kant are faced with a clash between Kant's empiricism and his defense of the synthetic a priori.

In his Commentary on the Critique, Hans Vaihinger summarizes a debate that had arisen over the paradox. ${ }^{3}$ Since space is given, it seems that space should

$1 \mathrm{KrV}$, A 23/B 37.12-38.13.

$2 \mathrm{KrV}$, A 25/B 39.21, emphasis Kant's. The reason for the usual translation of "Größe" as "magnitude" is to leave the English word "quantity" as a translation for "Quantität," and thus to distinguish the category of quantity from spatial or geometrical "magnitudes." Daniel Sutherland has argued that "magnitudes" have a distinct role in the Critical philosophy (Daniel Sutherland: "The Role of Magnitude in Kant's Critical Philosophy." In: Canadian Journal of Philosophy 34, 2004, 411-442). However, in this essay, Sutherland emphasizes the role of magnitudes in the Anticipations of Perception and the Axioms of Intuition, not in the Transcendental Aesthetic. Sutherland has also, following Michael Friedman, emphasized the influence of the Greek theory of proportions between magnitudes on Kant (Daniel Sutherland: "Kant on Arithmetic, Algebra, and the Theory of Proportions." In: Journal of the History of Philosophy 44.4, 2006, 533-558). In this essay, Sutherland observes that the use of "magnitude" or Kant's "Größe" can extend to numeric quantity as well: "Euclid, on the other hand, thought of numbers as magnitudes, since magnitudes are characterized as what can stand in ratios, and numbers can stand in ratios" (Sutherland 2006, footnote 16). In what follows, I will consider the term "Größe" to cover spatial magnitudes such as extension and figure.

3 Hans Vaihinger: Commentar zu Kants Kritik der reinen Vernunft zum hundertjährigen 
be actually infinite. In 1790, the mathematician Abraham Kästner published comments on Kant's concept of space in Eberhard's Philosophisches Magazin, arguing that there can never be an actual infinity present in space, even in geometrical construction, but only a finite, indeterminate magnitude that progresses toward infinity. ${ }^{4}$ For instance, a geometrical line can be drawn ad infinitum but never constitutes an actual, absolute infinite magnitude. In Kant's responses to Kästner, he makes a distinction between metaphysical and geometrical space:

Die Metaphysik muß zeigen, wie man die Vorstellung des Raumes haben, die Geometrie aber lehrt, wie man einen beschreiben, d. i. in der Vorstellung a priori (nicht durch Zeichnung) darstellen köne. In jener wird der Raum, wie er, vor aller Bestim̄ung desselben, einem gewissen Begriffe vom Objecte gemäß, gegeben ist, betrachtet; in dieser wird einer gemacht. In jener ist er ursprünglich und nur ein (einiger) Raum, in dieser ist er abgeleitet und da giebt es (viel) Räume, von denen aber der Geometer, einstimig mit dem Metaphysiker, zu Folge der Grundvorstellung des Raumes gestehen muß, daß sie nur als Theile des einigen ursprünglichen Raumes gedacht werden können. ${ }^{5}$

In 1801, Gottlob Schulze argues on the basis of this and other passages that, while Kant may mean that space is infinite and given, Kant is licensed only to argue that space is comparatively infinite. The representation of an actual infinity cannot be described as "given," because it goes beyond the boundaries of a possible experience. Schulze claims that Kant's commitments in the Antinomy doctrine mean that he cannot allow for an absolute (or actual) infinity present in experience. ${ }^{6}$ In other words, Schulze argues that Kant's empiricist and anti-metaphysical commitments are in conflict with his doctrine of the absolute infinity of space.

Vaihinger responds to Schulze that we can have access to a given, absolutely infinite space in experience. According to Vaihinger, Kant sees the original, a priori, subjective space as a kind of ability, namely, the ability of the subject to continue any space to infinity. The example of "drawing a line in thought" from the Deduction (at B 137-138) supports this interpretation, for instance. Further support comes from another passage that Vaihinger cites from Kant's discussion with Kästner:

Weñ nun der Geometer sagt, daß eine Linie, so weit man sie auch fortgezogen hat, imerer noch weiter verlängert werden köne: so bedeutet das nicht, was in der Arithmetik von der Zahl gesagt wird, daß man sie durch Hinzusetzung anderer Einheiten oder Zahlen imer und ohne Ende vergrößern köne [...], sondern eine Linie kan ins Unendliche fortgezogen werden heißt so viel als: der Raum, in welchem ich die Linie beschreibe, ist größer als eine jede Linie, die ich in ihm beschreiben mag; und so gründet der Geometer die Möglichkeit seiner Aufgabe, einen Raum (deren es viel giebt) ins Unendliche zu vergrößeren, aus der ursprünglichen Vorstellung eines einigen unendlichen, subjectiv gegebenen Raumes. ${ }^{7}$

Jubiläum derselben, second volume. Stuttgart 1892, $253 \mathrm{f}$. All translations from this work are mine. Vaihinger founded the journal Kant-Studien and wrote the seminal work Die Philosophie des Als-Ob (Berlin 1911).

4 Abraham Kästner: Ueber den mathematischen Begriff des Raums. In: Philosophisches Magazin, ed. Johann Eberhard. 2.4, 1790, 403-419.

5 RezKästner (Über Kästners Abhandlungen), AA 20: 419.01-10.

6 Schulze cites the passages at KrV, A 428/B 456 and following.

7 RezKästner, AA 20: 419.18-420.13. 
Vaihinger argues that this passage supports the interpretation that space is a representation of our subjective capacity or ability to represent space a priori as extending beyond any possible geometrical construction (e.g., a continued line) or represented body. The space that the subject represents to itself is infinite and given to the subject. However, Vaihinger argues, when Kant continues, he weakens his position by being ambiguous. Kant argues:

Daß aber der metaphysisch, d. i. ursprünglich, aber bloß subjectiv gegebene Raum, der (weil es dessen nicht viel giebt) unter keinen Begrif gebracht werden kann, welcher einer Construction fähig wäre, aber doch den Grund der Construction aller möglichen geometrischen Begriffe enthält, unendlich sey, damit wird nur gesagt: daß er in der reinen Form der sinnlichen Vorstellungsart des Subjects als Anschauung a priori besteht, folglich in dieser, als einzelnen Vorstellung, die Möglichkeit aller Räume, die ins Unendliche geht, gegeben ist. ${ }^{8}$

Vaihinger observes that following Kant's argument to this point leads to a further puzzle. Is "subjectively given space" a sensible, introspective representation of "the pure form of representation of the subject a priori", or is it a thought concept: the "possibility of all spaces, that go to infinity" ? As Vaihinger puts it, there are two possible ways to interpret the passage:

(1) The intuition of space is actually given to us as infinite,

(2) This infinity is only a thought one. 9

Vaihinger's dilemma leads to the question of whether (original, metaphysical) space is a concept that contains particular spaces under it, or whether it is a representation that contains particular spaces within it. The notion that a priori spatial relations are obtained through construction of concepts, or through geometrical construction, is known as the epistemic interpretation of Kant, whereas the view that spatial relations are given immediately in intuition or experience is known as the phenomenalist reading. Recently, Michael Friedman has defended the epistemic reading and Charles Parsons the phenomenalist reading of Kant on the infinity of space. Following Kant's own remarks in his response to Kästner, both have analyzed Kant's texts from the standpoint of trying to assess the necessary and sufficient conditions for geometrical construction.

Friedman assesses the difference between his and Parsons's interpretations in terms of how they spell out Kantian intuition, and in particular, "the role of intuition in Kant's theory of geometry".10 For Friedman, following Evert Beth and Jaako Hintikka, Kantian geometrical Anschauung (intuition) is needed to "generate singular terms in the context of mathematical reasoning in inferences such as we would represent today by existential instantiation."11 Kant's mathematical logic and his algebra do not allow him to demonstrate the existence of certain singular terms easily represented in geometrical construction, such as the diagonal of

8 RezKästner, AA 20: 420.15-421.04.

9 Vaihinger (1892), 256.

10 Michael Friedman: Geometry, Construction, and Intuition in Kant and his Successors. In: Between Logic and Intuition: Essays in Honor of Charles Parsons, ed. Gila Sher, Charles Parsons, and Richard L. Tieszen. Cambridge 2000, 186.

11 Friedman (2000), 186. 
a unit square, the square root of two, an example Kant discusses at length in the Nachlaß (see below for a discussion). Whereas we are able now to give a proof of the existence of such geometrical quantities independently of intuition, Kant was not, and so, Friedman argues, Kant harnesses geometrical intuition to fill the gap.

On Friedman's reading, geometrical intuition is necessary to represent certain magnitudes or quantities. Parsons observes that, even with the help of geometry, ordinary intuition does not appear to present us with a direct representation of a given infinite space. Like Vaihinger, Parsons sees a conflict between Kant's empiricist requirement that all synthetic reasoning be demonstrable in intuition and his argument that geometrical space is infinite. Parsons focuses on the fact that space is intended to be a form of intuition, and he points out that this gives rise to a problem:

Kant also supposed that space has certain mathematical properties which are reflected as properties and relations of the objects in space. It is of course the fact that they describe the form of our intuition which makes mathematical propositions a priori. Kant, of course, supposed that we know a priori that space is Euclidean. This means, in particular, that it is both infinite in extent and infinitely divisible. It is this which is the source of the difficulties. ${ }^{12}$

Parsons sees these difficulties as arising from the fact that the "doctrine of continuous space as a form of outer intuition" prima facie conflicts with "the fact of the limited acuteness of our senses". ${ }^{13}$ Parsons points out that if space is infinite in extent and in divisibility, and if we perceive it as such, then, on the most obvious reading of Kant, our senses ought to be able to perceive series of infinite extension, and infinitely divisible objects, directly. If continuous space is the form of outer sense, then objects of sense should be given to us as continuous. This would mean, though, that when representing a line, we would be able to in some way represent to ourselves each of the successive infinitely small parts of the line (for Kant, the component spaces of the line) at the same time. In other words, each of the infinitely small parts of the line would be explicitly given to us at the same time. But this does not seem possible for us.

Parsons resolves these difficulties by distinguishing between explicit and implicit givenness, based on the distinction in Gestalt psychology between "figure" and "ground". In our perceptions, we are presented initially with a physical object, say, which is the "figure". But within that explicitly given perception, there are additional aspects of the object, not given explicitly with our initial representation. When we shift focus, we are able to represent these. These aspects may include subtle degrees of color, variations of shape, and spatial divisions. Parsons concludes that Kant meant to say that "whatever appears to us as ground can become figure," which Parsons calls the "Continuability Principle". ${ }^{14}$ When we represent a figure, it is at the same time given to us that we can focus on a distinct part or aspect of that figure at will. This change of focus makes available a differ-

12 Charles Parsons: Infinity and Kant's Conception of the 'Possibility of Experience'. In: Kant's Critique of Pure Reason: Critical Essays, ed. Patricia Kitcher. Lanham 1998, 39.

13 Parsons (1998), 45.

14 Parsons (1998), 47. 
ent set of quantities, e.g., degree of color, and the change from one set of quantities to another is continuous. For instance, we can shift focus from the outline or borders of a figure to its color without intervening steps. In this sense, space as we perceive it is an infinite quantity given in experience. A boundless spatial horizon is necessary to the type of representations we have of objects of experience.

Friedman objects to Parsons's claim that infinite space, or at least spatiality, is given to us immediately in perception. Based on his logical or epistemic reading as outlined above, Friedman points out that we could regard infinite space as a necessary and sufficient a priori condition for geometrical construction, and, in particular, for the concrete representation of certain types of geometrical particulars. According to Friedman, it is in this sense, as a part of the process of geometrical construction, that Kant considers space to be an infinite, given form of intuition. For Friedman, that space is "given" does not mean that the infinite parts of the objects of our representations are given to us at once, but rather that geometrical construction can reveal to us continuous quantities not otherwise accessible. Geometrical, and not ordinary, "intuition," then, is the source of the givenness of infinite space. This conclusion leads to a characteristic feature of Friedman's account. Some set of spatial concepts is necessary a priori to construct, or constitute, the objects of intuition and, in particular, the objects of geometry and of physics. We know that the quantity "the square root of two" exists, because it is given in geometrical construction as the length of the diagonal of a unit square, but that quantity cannot be accessed in sensible intuition without an a priori spatial concept under which to subsume it.

In remarks on the debate between Parsons and Friedman, Emily Carson argues that Friedman cannot be right that the infinity of a priori space comes from geometrical construction. For in his correspondence with Kästner, Kant makes a clear distinction between metaphysical and geometrical space, and it is metaphysical space that is meant to ground our geometrical constructions. Carson argues that metaphysical space is given as unique and boundless independently of geometrical construction:

Whereas Friedman takes the essential feature of space underlying the arguments of the Metaphysical Exposition to be infinite divisibility as revealed by geometry, I want to suggest rather that the essential feature is the uniqueness and boundlessness of space as a condition for the possibility of experience, from which the infinity of geometrical space is supposed to follow. This is a claim about the space of experience, how space is given to us independently of and indeed prior to geometry, and it is this experience which serves as data for Kant's synthetic method. ${ }^{15}$

Carson argues that Friedman cannot be correct that the infinity of metaphysical space is a result or byproduct of geometrical construction, because Kant says quite clearly in his response to Kästner that metaphysical space is prior to geometrical space and is a precondition for geometrical construction.

15 Emily Carson: Kant on Intuition in Geometry. In: Canadian Journal of Philosophy 27, December 1997, 496. 
I agree with Carson that Friedman's initial view is wrong here. However, I think that several related questions remain about how to conceive of the relationship between metaphysical and geometrical space. First, Carson argues that metaphysical space is "unique" and "boundless" in Parsons's sense, that is, that "the uniqueness of space is indicated by the fact that particular spaces are given in one all-encompassing space." 16 As seen above, Parsons cashes out this view in terms of Gestalt psychology and the possibility of continuous changes of focus between figure and ground. But if Kant really did hold a view like this, what was his account to mirror Parsons's Gestalt explanation?

Second, Friedman has conceded to Carson that geometrical construction cannot be the source of the infinity of metaphysical space. ${ }^{17}$ But Friedman remarks that there remains a problem for the phenomenalist view. The infinite metaphysical space that Kant wants to use to "justify or verify the possibility of Euclidean constructions" cannot be "directly seen". We do not have "direct perceptual or quasi-perceptual access to such infinity entirely independently of geometry". In particular, Friedman objects to Parsons's continuability principle that "since the visual field is itself always finite, it does not even appear to be true that any perceived spatial region is directly given or perceived as part of a larger such region." 18 Even if one accepts the phenomenalist account, it does not prove that an actual infinite space is given in experience. Parsons's principle is the "continuability," not the "actually continuous" principle. Parsons's method is grounded on an activity of the subject as well as on the facts revealed to us in spatial perception. As Carson observes, on the phenomenalist account the uniqueness and boundlessness of metaphysical space rests on the fact that metaphysical space is a condition for the possibility of experience.

On the basis of these considerations, Friedman also concludes that the infinity of space is grounded on an activity of the subject, but he focuses instead on the a priori "figurative synthesis" of the imagination. Thus, if successful, Friedman's account will answer the first question I raised above, of how to demonstrate that Kant himself would have agreed with these interpretations. The figurative synthesis of the imagination allows the subject to draw a straight line in thought and then rotate such a line around a fixed point, as Kant puts it. ${ }^{19}$ The figurative synthesis, for Friedman, is the source of our ability to construct geometrical proofs. And it is the source of the unity and of the infinity of space:

the subject can imaginatively change the given point of location by a translation through space and imaginatively change its given orientation by a rotation around this point. Moreover, by an appropriate combination of such translations and rotations the subject can thereby imaginatively put itself in position to perceive any outer object located anywhere in perceptual space. It is in this sense, I believe, that perceptual space is necessarily both singular or unitary and infinite or unbounded. ${ }^{20}$

16 Carson (1997), 499.

17 Friedman (2000), $188 \mathrm{f}$.

18 All the above citations are from Friedman (2000), 189.

19 Friedman (2000), 189, cites the passage at RezKästner, AA 20: 410-411.

20 Friedman (2000), 192. 
The "pure formal structure of perceptual space" is the ability of the subject to imaginatively change its perspective without limit. Friedman's revised account resembles Parsons's in this respect, but a significant difference remains.

For Parsons, the possibility of changing focus or orientation in space is given in experience. When a subject "continues" a spatial representation by changing focus to an element of the representation that hitherto was in the background or on the horizon, she does not introduce a new element. Instead, she synthesizes material that has been given in the initial representation - what Kant refers to in the A edition as the reproductive synthesis of the imagination (A 100-102). In contrast, Friedman appeals to the productive, figurative synthesis of the imagination a priori (A 162/B 203 and following). The figurative synthesis, the subject's ability to orient herself in space and time, is independent of given representations. Instead, the figurative synthesis is constitutive of our intuitions, as Kant says explicitly (A 179/B 221 and following). However, the figurative synthesis is described in the Axioms of Intuition, that is, in the Transcendental Analytic, not in the Transcendental Aesthetic. Can the figurative synthesis be a necessary condition of metaphysical space? Must we presuppose the results of the Analytic to justify the results of the Aesthetic?

Indeed, Friedman's account departs deliberately from Kant's original presentation at just this point. Following Robert DiSalle, Friedman looks to Hermann von Helmholtz to back up the procedure of figurative synthesis. Bernhard Riemann's "axiom of free mobility" has it that space has constant curvature only under the assumption that spatial objects can be moved anywhere in space without deforming - shrinking or tearing, for instance. ${ }^{21}$ Helmholtz specified the most general, abstract geometrical axioms that must hold for us to be able to construct any geometrical space. Helmholtz argued that the set of rotations and translations that preserve a figure's form make up a set of "rigid motions," and that geometers must assume some set of rigid motions to be able to construct any space of constant curvature. ${ }^{22}$ Friedman's solution makes rigid motions primary and any particular set of geometrical axioms secondary, which has a great deal to recommend it. First, it makes sense of the distinction between metaphysical and geometrical space. Second, it allows for Friedman's own account, again following Helmholtz, according to which the choice between particular sets of axioms is free (Euclidean axioms are not necessary unless you wish to limit yourself to constructing a space of zero curvature) and only free mobility is necessary.

But I do not think that Friedman's account goes far enough yet to constitute a complete interpretation of Kant's theory of metaphysical space. Friedman has yet again constructed a view according to which metaphysical space results from an a priori synthesis. Whether this synthesis is the figurative synthesis of the imagination

21 Bernhard Riemann: Ueber die Hypothesen, welche der Geometrie zu Grunde liegen. In: Bernhard Riemanns Gesammelte Mathematische Werke, ed. Richard Dedekind and Heinrich Weber, second revised edition. Leipzig 1892 [1854], 285, my translation.

22 Hermann von Helmholtz: Über die Thatsachen, welche der Geometrie zu Grunde liegen. In: Wissenschaftliche Abhandlungen, Volume II. Leipzig 1883, 618-639. Originally published in the Nachrichten von der Königl. Gesellschaft der Wissenschaften zu Göttingen. No. 9, 3 June 1868. 
or not, this move contradicts Kant's remarks in the correspondence with Kästner that metaphysical space cannot be brought under any constructible concept:

[E]ine Linie kan ins Unendliche fortgezogen werden heißt so viel als: der Raum, in welchem ich die Linie beschreibe, ist größer als eine jede Linie, die ich in ihm beschreiben mag; und so gründet der Geometer die Möglichkeit seiner Aufgabe, einen Raum (deren es viel giebt) ins Unendliche zu vergrößeren, aus der ursprünglichen Vorstellung eines einigen unendlichen, subjectiv gegeben Raumes [...]. Daß aber der metaphysisch, d. i. ursprünglich, aber blos subjectiv gegebene Raum, der (weil es dessen nicht viel giebt) unter keinen Begrif gebracht werden kan, welcher einer Construction fähig wäre, aber doch den Grund der Construction aller möglichen geometrischen Begriffe enthält, unendlich sey, damit wird nur gesagt: daß er in der reinen Form der sinnlichen Vorstellungsart des Subjects als Anschauung a priori besteht, folglich in dieser, als einzelnen Vorstellung, die Möglichkeit aller Räume, die ins Unendliche geht, gegeben ist. ${ }^{23}$

There are many geometrical spaces, as Kant says here, but only one a priori, subjectively given, original, metaphysical space. Metaphysical space cannot be subsumed under a concept of quantity because there is, necessarily, only one metaphysical space, the a priori representation of space.

According to Friedman, metaphysical space is based on the axiom of free mobility plus the subject's ability to place itself in distinct perspectives, to access any object in any spatial position. Thus, for Friedman, the unity of metaphysical space can be based only on the unity of the synthesis of paths through space from an initial standpoint. But the basis of this unity is given to us through construction, whether imaginative or not. Why should the subject's ability to synthesize or to "perceive" outer objects necessarily be single and original, in that case?

Thus, I do not see how metaphysical space is shown to be necessarily single, on Friedman's view. The only sense in which the group of rigid motions necessarily must form a single "space" a priori is the sense in which the subject's ability to place itself in an infinite number of perspectives must stand under the conditions for a possible unified experience. ${ }^{24}$ But, again, how is the proof that this space is single to go? Is there a way to express the proof without appealing to geometrical construction? Friedman himself realizes that this is a problem, and he appeals to the claim that "all outer objects must be reachable via translation and rotation, as it were, from a single initial given point of view." 25 But this is a statement about the possible paths through space that a subject can take from an initial standpoint, not a statement about why that initial standpoint itself is necessary, for instance (see concluding remarks). I do not think that Friedman's take is wrong, but I do think we can say more about what Kant means here.

At this point, Parsons might argue that Friedman's account reaches an impasse, out of which Parsons's own account can lead us. The epistemic or logical reading

23 RezKästner, AA 20: 420.07-421.04.

24 Helmholtz and Poincaré saw the group of rigid motions as constructed from sense experience. See, e.g., Gerhard Heinzmann: The Foundations of Geometry and the Concept of Motion: Helmholtz and Poincaré. In: Science in Context. 14. September 2001, 457-470. For them as well, while the group of rigid motions is a single set by virtue of being referred to a single subjective experience, it is not necessarily single a priori.

25 Friedman (2000), 192. 
cannot account for the given unity of consciousness, i.e. Friedman's "single initial given point of view" - and we need a phenomenalist account precisely because we need to represent that unity. But I am not sure that Parsons's Continuability Principle can account for the unity of space either. The continuability of perceptual quantities when changing focus is accessible to us in perception, yes. Is that "continuability" a part of the representation of space or a concept we must assume to represent space as we do? If the continuability of metaphysical space is a part of the representation, then why is it a necessary unity a priori? One of Parsons's descriptions of infinity is that in each continuation of a line we perceive a boundless horizon in which to extend that line. But the fact that with every representation we represent a boundless horizon does not prove that those horizons constitute a unique metaphysical space. Is it because we are aware that the ability to extend the line originates with us? If that is the case, then what feature of the subject as origin explains the necessary unity of metaphysical space? The bare fact that the subject is physically singular, for instance, is not enough for Kant to argue that the subject occupies a fixed, given point of view. If, on the other hand, continuability is a concept necessary to explain our experience, then why can it not be subsumed under a constructed concept? When changing focus, we pass through and run together distinct perceptions within the visual field, that is, we synthesize them. If the infinity of that field is given to us in perception, then it is an infinity based on synthesis, and again, metaphysical space is supposed to be the precondition for that synthesis, not its result.

While the debate between Friedman, Parsons, and Carson arguably has cleared up Vaihinger's conundrum by referring the givenness of metaphysical space to the perception, whether empirical or geometrical, of an ability of the subject, the difficulties I've raised remain. I argue that there is a natural way to read Kant here on metaphysical space, a way that will resolve most of the paradox of infinite given magnitude, and many of the difficulties I've raised above. I think I can explain how Kant thought metaphysical space "cannot be brought under any concept capable of construction," and how he thought such a space is a necessary condition of geometrical construction. Finally, I will show how this role for metaphysical space is crucial Kant's epistemological argument in the Critique. I argue that, bracketing the difficulties with proving uniqueness, Kant's argument is an ingenious way to reconcile empiricism with the doctrine of the transcendental ideality of space and time. However, I do not think that the problem of the uniqueness of metaphysical space is resolved so easily.

Kant argues, frequently, that magnitude $[\mathrm{Größe}]$ is generated in time according to a rule. Interestingly, this seems to re-locate the difficulties I've raised with Friedman's and Parsons's interpretations to an apparent inconsistency within Kant's own stated views. Kant describes metaphysical space in the Critique as an infinite given magnitude, he argues that all magnitude is constructed or generated according to a rule, and then he argues in the correspondence with Kästner that metaphysical space "cannot be brought under any concept capable of construction." 26 How can all of these statements be true at the same time? If metaphysical space is a 
magnitude, then, according to Kant, it is constructed according to a rule. In that case, it should be possible to subsume it under a constructed concept.

But the metaphysical space Kant calls infinite in the Aesthetic is a single space that is the origin of all generations of magnitude. As a result, all generated magnitudes must be thought as subsets of the series of possible determinations of the original, single space that Kant describes in the Aesthetic. Kant describes this original space as the representation that makes possible the distinction of the space the subject occupies from the space an external object occupies. ${ }^{27}$ Any constructed geometrical space is part of the set of determinations that originate from metaphysical space, i.e., from the a priori representation of space that makes possible all measurement of spatial magnitudes external to the subject.

Kant argues, further, that the set of constructed geometrical magnitudes is a subset of the set of magnitudes generatable from the original representation of space. As Kant continues in his correspondence with Kästner,

In jener [Metaphysik] ist er ursprünglich und nur ein (einiger) Raum, in dieser [Geometrie] ist er abgeleitet, und da giebt es (viel) Räume, von denen aber der Geometer einstiming mit dem Metaphysiker, zu Folge der Grundvorstellung des Raumes gestehen muß, daß sie nur als Theile des einzigen ursprünglichen Raums gedacht werden können. Nun kann man eine Größe, in Vergleichung mit welcher jede anzugebende gleichartige nur einem Theile von ihr gleich ist, nicht anders als unendlich benennen. ${ }^{28}$

Here Kant calls metaphysical space a Größe, a word he uses for geometrical magnitudes and arithmetical quantities alike. Now if we are to distinguish metaphysical space, which is the ground of the possibility of conceptual construction according to a rule, from geometrical space, which is the result of such construction, then we must know what characteristic of metaphysical space means that it is not subsumable under any constructable concept. To make the problem more difficult, according to this passage we must regard the "original" space as the same thing when represented metaphysically and geometrically. Here Kant simply says, the representation of space, and it is clear from the context that he means the representation of the "original space" by the metaphysician and by the geometer are the same: they represent it as "infinite-given".

But in what sense of "infinite"? Here is the crux. Kant describes an infinite magnitude in this context as "eine Größe, in Vergleichung mit welcher jede anzugebende gleichartige nur einem Theile von ihr gleich ist”. Kant's argument here may be drawn from Kant's reflections on the so-called Galileo's Paradox, which, though it did not originate with Galileo, was presented in Two New Sciences, a work with which Kant was familiar. ${ }^{29}$ According to Galileo, a set is infinite if it can be put into one-to-one correspondence with at least one of its proper subsets. As I've said above, Kant says that metaphysical space is infinite in this sense.

The basis of the infinity of metaphysical space is the fact that constructed geometrical spaces are a proper subset of the determinations of the single metaphys-

27 Cf. KrV, A 23/B 38.20-26.

28 RezKästner, AA 20: 419.06-13.

29 I would like to thank an anonymous reviewer for Kant-Studien for pointing out the relevance of Galileo's Paradox here. 
ical space, and that geometrical spaces can be put into one-to-one correspondence with metaphysical space. But to say so does not explain how or why this is true, for Kant in particular. Why should it be the case that the set of geometrical magnitudes is not coextensive with metaphysical space, for instance? What distinguishes the set of geometrical magnitudes from metaphysical space? Kant could have meant that metaphysical space is a condition for the possibility of geometrical magnitudes but is not different in kind: that the two sets are coextensive. However, as Carson and I emphasize, Kant is very sure in the correspondence that there is a clear distinction.

Metaphysical space is the single, original space. As Kant argues in the Principles, the original, pure intuition of space has the magnitude zero. ${ }^{30}$ Thus, if part of Kant's goal in the Aesthetic is to give the a priori conditions for calculating geometrical magnitudes that are generated in time according to a rule, then what Kant means by "infinite" here becomes clearer. There is a well-defined type of comparison of what we would call vector quantities and what Kant and Newton called fluxion quantities, according to which any two given similar such quantities sum to zero: if they are oriented in opposite directions. If a magnitude, a line, for instance, is drawn on paper, it has a determinate spatiotemporal orientation. But if we draw that magnitude, the line, in thought a priori, its orientation is indeterminate. In particular, regarded as a scalar quantity, any line drawn in thought has two possible directions associated with it: two possible directions in which it could be drawn. In other words, when we draw a line on paper, it must be drawn from point A to point B or from point B to point A. But when we draw that line in thought, we can imagine that it be drawn in either direction, by employing the rule-governed figurative synthesis of productive imagination. The same holds true for any geometrical figure. Any geometrical magnitude generated in a determinate direction with respect to the subject's position is "only a part" of the set of similar magnitudes that can be generated by the subject from her position at the origin of generations of magnitude.

Magnitudes generated in geometrical construction are oriented, that is, such magnitudes have a specific direction, whereas figures drawn in thought do not. Kant argues that we can know certain geometrical magnitudes only because they are generated in time. He does so in the Reflexionen when explaining how we can justify our knowledge of irrational quantities such as the square root of two, even though we cannot represent them as finite fractions:

Wenn wir nicht Begriffe vom Raum hatten, so würde die Große $\sqrt{ } 2$ für uns keine Bedeutung haben, weil man sich alsdann jede Zahl als Menge untheilbarer Einheiten vorstellen könnte. Nun stellen wir uns eine Linie als durch fluxion, mithin in der Zeit erzeugt vor, in der wir nichts Einfaches vorstellen, und können 1/10, 1/100, etc. etc. von der gegebenen Einheit denken. ${ }^{31}$

30 See, e.g, KrV, A 188/B 233.14-234.31 and KrV, A 165/B 208.10-24. See especially KrV, A 207-208/B 253.15-22, where Kant argues that alteration, considered a priori, is the difference in magnitude between "the pure intuition $=0$ " and a determinate magnitude.

31 Refl, AA 14: 53.02-07. 
Note the final claim, that since we represent lines to ourselves through fluxion, we can represent continuous quantities "von der gegebenen Einheit". Kant says in the previous sentence that every algebraic number (scalar) is a "Menge untheilbarer Einheiten". 32 But the set of scalar quantities is only part of the set of spatial magnitudes that can be synthesized "von der gegebenen Einheit". 33

If we consider a scalar line to be a set of single spaces or points, then the same line, considered as a magnitude generated in time, always can be compared a priori to the magnitude generated in the opposite direction but with the same scalar quantity, and the two magnitudes will sum to zero. For instance, take the line between point $\mathrm{A}$ and point $\mathrm{B}$. We can represent that line as line $\mathrm{AB}$, but it is indifferent a priori whether it is $\mathrm{AB}$ or $\mathrm{BA}$. The two vector or fluxion quantities, $\mathrm{AB}$ and $\mathrm{BA}$, sum to zero. In other words, if you begin at point $\mathrm{A}$, draw a line to point $B$, then draw the line back from point $B$ to point $A$, you end up where you began.

Here is where Kant sees his transcendental idealism as falling in line with his empiricism. When the geometer draws a line, she is generating a scalar quantity, but since that line is drawn in time, for Kant it is also a magnitude generated in time, or what Newton called a "fluxion" quantity. In 1790, Kant writes in the Reflexionen on the Critique:

32 As Kant remarks in the Reflexionen, "Die Gegenstande der Arithmetik und Algebra sind ihrer Moglichkeit nach nicht unter Zeitbedingungen, aber doch die construction des Begrifs der Größe [so fern diese Gegenstande durch] in der Vorstellung derselben durch die Synthesis der Einbildungskraft, nemlich die Zusammensetzung, ohne welche kein Gegenstand der Mathematik gegeben werden kan. Algebra ist eigentlich die [allgemeine Verbindungskunst] Kunst, die Erzeugung [der Größen] einer unbekannten Größe durchs Zählen unabhängig von jeder [gegebenen] wirklichen Zahl blos durch die gegebene Verhältnisse derselben unter eine Regel zu bringen. Diese zu erzeugende Größe ist immer eine Regel des Zählens, wornach die Größe bestimmt [gegeben gedacht] werden kan, zum Beyspiel die Diagonallinie eines Qvadrats, aber nur in der Construction, nicht durch eine Zahl, sondern [ein] durch ein Zeichen des Zählens $\sqrt{ } 2$, welches den Begrif einer Größe bedeutet, [zu deren Begrif vermittelst einer] [zu dem] der nur die Regel der Annäherung [zu einer] des Zählens zu einer Zahl, welche die letztere ausdrükt, bedeutet. Daß eine solche Größe möglich sey, würden wir ohne die Geometrie nicht wissen. Aber ohne Arithmetik (noch vor der Algebra) würden wir von der Diagonallinie des Qvadrats auch keinen Begrif seiner Größe haben können" (Refl, AA 14: 54.05-55.02).

33 A reader might object that I am building in too much of Newtonian science. As Carson observes when objecting to Friedman's logical reading, Kant's goal in the Critique was not to back up any particular scientific result, including Newton's results in the Principia. This distinguishes the Critique from the Metaphysical Foundations and the Prolegomena, in which Kant gives concrete examples from science. In the Critique, Kant is concerned to give a philosophical argument following the synthetic method, "was noch nichts als gegeben zum Grunde legt außer die Vernunft selbst und also, ohne sich auf irgend ein Factum zu stützen, die Erkenntniß aus ihren ursprünglichen Keimen zu entwickeln hat" (Prol, AA 04: $\mathbb{4}$ 4, lines 32-35, cited in translation in Carson (1997), 495, emphasis added by Carson). But fluxion quantities are generated in time. It is well known that Kant writes in the Critique of time as being the form for the generation of quantity. Although Kant is not appealing directly to Newton's fluxion concept in its particulars, he certainly uses the notion of fluxion quantity in the Critique, in the Reflexionen, and in his response to Kästner. 
Im Raumes Vorstellung ist zwar nichts von Zeit gedacht, aber [so fern] in der Construction [ders] des Begrifs von einem gewissen Raum, e.g. einer Linie [wie]. Alle Größe ist Erzeugung in der Zeit durch wiederholte position eben desselben. ${ }^{34}$

If direction in time is not determinate a priori, then any geometrical line could be oriented in either direction. A line drawn from point A to point B has the same scalar quantity, the same measure, as the line drawn from B to A. In that sense, the geometer sees the line as a single series of monadic spaces, whereas the metaphysician sees the line as two potential magnitudes generated and directed in time. This is what Kant means when he says that the geometer and the metaphysician are working with the same space. But the metaphysician's knowledge that the line could be oriented in either direction is necessarily a priori, because direction in time is not observed directly in outer experience. However, direction is observed immediately in inner sense, that is, in time. In Kant's terms, direction, or orientation, is not an empirical concept derived from the appearances. Necessary, or determinate, direction or orientation can be constructed only in the form of time determinations, according to the Principles as rules for synthesis.

For Kant, that any succession in time can be oriented in either direction follows from the transcendental ideality of space and time, and in particular, from the fact that space and time are "epistemic conditions" for representing objects, as Henry Allison puts it. ${ }^{35}$ Kant's metaphysical space is analogous, not to the broadest possible group of rigid motions derived from imaginative construction, but to the set of invariant spatial magnitudes that can be generated in opposite directions a priori. 36

From a more contemporary standpoint, a rigorous proof of such a result would require information about, for instance, symmetry relations. Friedman's account of the figurative synthesis of the imagination as making possible changes in our perspective based on the group of rigid motions of rotation and translation is an obvious source of our knowledge of such relations. Proving that two similar quantities, two lines, for instance, have the same measure (scalar quantity) but distinct directions will depend on our ability to reverse any rotatation or translation. Thus, the interpretation of Kant that I defend limits Friedman's account of the figurative synthesis to symmetrical or reversible rigid motions a priori. For Kant, the invariance of the measure of these magnitudes is guaranteed by the rules for generating magnitudes in time, not by atemporal invariance relations such as the axioms that determine Helmholtz's groups of rigid motions.

34 Refl, AA 14: 54.01-04.

35 Henry Allison: Kant's Transcendental Idealism. New Haven 1983, Chapter 5, esp. 85 f.

36 In the $19^{\text {th }}$ century, neo-Kantians argued that this space could be given a more specific incarnation as the set of possible symmetric or reversible orientations in space, that is, the group of invariant transformations. Ernst Cassirer, an influence on Friedman, was perhaps the first to develop this interpretation. According to Cassirer, "Each special form of geometry is coordinated with a definite group of transformations as its appropriate theory of invariants, and these can be strictly defined and set over against each other." Interestingly, Cassirer appeals to James Clerk Maxwell's Matter and Motion in the presentation of his views. See Ernst Cassirer: Substance and Function, trans. William Swabey and Marie Swabey. Chicago 1923, $249 \mathrm{f}$. 
My account extends Kant's explicit views about space and time, by interpreting Kant's figurative synthesis in terms of relations of symmetry, i.e., of invariance. However, Kant was aware that symmetry or proportion was significant for his theory. As I mentioned in a note above, Daniel Sutherland and Michael Friedman have emphasized the influence of Eudoxus's proportion theory on Kant's mathematics. Giora Hon has argued recently that Kant elaborates on the notion of symmetry in 1768 with "Concerning the Ultimate Ground of the Differentiation of Directions in Space," but that Kant stopped short of developing a mathematical account and contented himself with a metaphysical account, according to which symmetry is a type of balance or proportion. ${ }^{37}$

The balance of the evidence thus supports the claim that the best way to resolve the paradox of infinite given magnitude is to argue that metaphysical space is the set of equal and opposite a priori transformations of the subject's perspective, that is, of rotations and translations that generate magnitudes with the same scalar measure but opposite orientations. Only these motions have the crucial feature of summing to zero and thus constituting a single metaphysical space.

The figurative synthesis of the imagination is made possible by the fact that such a space "exists". Given any generation of a magnitude going in one direction, the subject always can generate a magnitude going in the opposite direction. That is, if the subject can draw a line from A to B, that subject can draw a line from B to A. Such is a necessary a priori condition for thinking of metaphysical space in the first place. Further, such a space is infinite-given, because for metaphysical space to be thinkable any given scalar quantity must be orientable in a number of directions. For instance, with any given scalar line, two opposite magnitudes generated in time are given that represent the possible directions it can be generated in time. These magnitudes are associated with the same scalar quantity, which can be given in experience. Thus, Kant can argue that metaphysical space is infinite and given without transgressing the bounds of a possible experience.

The invariant position at the origin of all generation of magnitude is the subject's a priori representation of space. Kant wants the original representation of space to be the single representation that is at the ground of the generation of all possible geometrical magnitudes. While I am not sure that his arguments on this score are ultimately plausible, my goal was to show why Kant thought metaphysical space cannot be subsumed under a concept. For Kant, since the original representation of space a priori is single, there is no other representation that stands in a determinate relation to it, and so it cannot be subsumed under a concept. As Kant says in the citation above from the Kästner correspondence, the representation of space cannot be subsumed under a concept "because it is not the case that there are many" such original representations of space: "weil es dessen nicht viele giebt".38

37 Giora Hon: Kant vs. Legendre on Symmetry: Mirror Images in Philosophy and Mathematics. In: Centaurus 47, 2005, 283-297.

38 In context, the "es dessen nicht viele giebt" here does not mean "there are not many" in the sense of "there are only a few." Instead, Kant means that, while there are many geometrical spaces (as he says in the passage just before this one), it is not the case that there 
The "boundless horizon" to which Parsons appeals is guaranteed by the fact that the figurative synthesis is the basis of the rule-governed synthesis described in the Schematism. Kant's rules for the figurative synthesis govern the generation of geometrical magnitudes with a determinate orientation in space and time with respect to the subject. But the same rules are valid for the subject to generate a further set of magnitudes in thought, with the same scalar quantity as the originally generated magnitudes, but with a distinct orientation with respect to the subject's spatial position. ${ }^{39}$

Friedman, on the other hand, argues that, for Kant, the figurative synthesis of the productive imagination a priori is a condition for the infinity and unboundedness of space. Again, while I think the general view is correct, I do not agree with Friedman's account of why this is the case. Friedman focuses on the ability of the subject to put herself in different perspectives with respect to the objects of experience:

the subject can imaginatively change the given point of location by a translation through space and imaginatively change its given orientation by a rotation around this point. Moreover, by an appropriate combination of such translations and rotations the subject can thereby imaginatively put itself in position to perceive any outer object located anywhere in perceptual space. It is in this sense, I believe, that perceptual space is necessarily both singular or unitary and infinite or unbounded. 40

According to this account of metaphysical space, the figurative synthesis would end with the determination of a set of magnitudes. There would be no reason to conclude that those magnitudes, as a collection, have any special properties, including the special property of being a single space that Kant refers to above. Further, as a set of determinate magnitudes, metaphysical space would be subsumable under the category of quantity.

I focus, instead, on the ability of the subject to generate magnitudes with the same scalar quantity, but oriented oppositely with respect to the original representation of space. Similar magnitudes oriented distinctly with respect to the subject's original representation of space are generated by the figurative synthesis. Once she has generated any one magnitude, it is given to the subject that she can generate a magnitude of the same scalar quantity oriented oppositely with respect to her original representation of space. Thus, the figurative synthesis a priori in principle ought not end with the generation of a determinate quantity, including a determinate path through space or the determination of an object of perception. Instead, the result of the figurative synthesis is the construction of a set of spatial relations, pairs of oppositely oriented magnitudes, that cannot be determined further a priori. In particular, the figurative synthesis alone cannot determine a positive quantity without the rules for necessary time determination, the Principles.

are many metaphysical spaces: there is only one, the single, original representation of space. Even time is not similar to space, because time is one-dimensional and space manydimensional, as Kant remarks.

39 Cf. KrV, A 140/B 179.25-37.

40 Friedman (2000), 192. 
It is crucial to Kant's epistemology that Kant be able to prove that metaphysical space (a) is a set of relations that are neutral in orientation and (b) is conceptually prior to geometrical, and in particular to constructed, space. Geometrical spaces are constructed using magnitudes generated in a particular direction in a finite time, and so geometrical space in Kant's sense does not have the necessary epistemological quality that all such quantities must sum to zero a priori over the space as a whole. Only the set of symmetrical, invariant transformations a priori has such a quality. All constructed geometrical spaces (metric spaces) can be regarded as constructed within and as continuous with the set of all potentially constructible fluxion quantities.

Given this fact, Kant can make the epistemological argument that any determinate geometrical proof a priori that a given quantity must be oriented in one direction or another is objectively meaningful, which is how synthetic judgments a priori are possible in geometry. ${ }^{41} \mathrm{He}$ can make the further argument that any physical proof that gives a determinate direction for a given change proves that the change is real, because it can determine a real quantity, that is, a magnitude that does not sum to zero. In fact, Kant can demonstrate that a change is real if and only if it can be represented as a determinately directed quantity, which, I would argue, is what he does in the Analogies.

Kant can make the argument above only if the subject occupies a given, fixed standpoint with respect to objects of experience. The subject's standpoint, on my interpretation of Kant, is the standpoint from which, considered a priori with respect to their form, the set of spatial magnitudes of equal scalar quantity that can be generated in time from that single position sum to zero. Only if that is the case is metaphysical space unique or single. Thus, a central question raised by the debate between epistemic and phenomenalist interpretations of Kant's doctrine of space and time is how Kant proposes to prove that the subject occupies a fixed standpoint. Answering this question requires making decisions about how the moving parts of Kant's system fit together. If we say that Kant supports the claim that the subject occupies a fixed position with regard to the objects by appealing to the argument that space and time originate with the subject, as the forms of subjective intuition, then some of the arguments in the Metaphysical Expositions begin to appear to have gaps or even to be circular. Kant argues that a priori space is single, infinite, and given in the Exposition of the concept of space. But if it turns out that the singleness of space depends on a prior commitment to the subject as origin of ideal space, then the conclusions of transcendental idealism are being brought in to buttress some of the primary arguments for transcendental idealism.

An epistemic interpretation that does not appeal to pure intuitions of the subject could argue that the mathematical unity of apperception guarantees the fixture of the subject's standpoint, and indeed the above interpretation gives some support to such a move. But if we appeal to the unity of apperception, then the

41 It is interesting to read the famous passage beginning at $\mathrm{KrV}$, A 713/B 741.8-742.26 with this interpretation in mind. 
Transcendental Analytic is being brought in to support the Aesthetic. It's possible to avoid doing so by making the mathematical unity of apperception regulative, and not constitutive, of our intuitions. In that case, though, the unity of apperception would no longer be given as a presupposition of subjective experience. Michael Friedman's own argument in the Dynamics of Reason for the plurality and relativity of the constitutive mathematical frameworks of physical theories is an example of such an approach. ${ }^{42}$

While the problem of the necessary unity and uniqueness of metaphysical space remains, the great advantage of Kant's distinction between metaphysical and geometrical space is that it allows him to reconcile most aspects of transcendental idealism with his empiricism. A geometrical line, for instance, is at one and the same time a "set of indivisible unities", that is, the "repeated position" of an observable point, and a continuous magnitude generatable in either direction, and thus part of an infinite set, in Kant's sense, of possible a priori transformations. With this account, Kant can respond to skepticism about causality without arguing that synthetic a priori judgments, and causal judgments in particular, originate in the mind. If the magnitude or quantity of any possible alteration, considered only as a change in space and time, is zero a priori, then it is at least plausible prima facie that a judgment based on a unique determination of a positive magnitude in time and space will be objectively meaningful. ${ }^{43}$

42 Michael Friedman: Dynamics of Reason. Stanford 2001.

43 Acknowledgements: I would like to thank Emily Carson and Alison Laywine for extensive discussions of my earlier work on these subjects. 